\title{
A Monarquia Segundo JEAN-JACQUES ROUSSEAU
}

\section{Renato Moscateli ${ }^{1}$}

$\mathrm{N}$

a maior parte das vezes, o nome do filósofo suíço Jean-Jacques Rousseau é associado às origens da democracia moderna, em razão da defesa que 0 autor apresentou, em suas obras, da soberania popular e da vontade geral, esta última sendo o fundamento da lei em uma república ideal. Entretanto, Rousseau não se limitou a refletir sobre como se poderia construir um Estado democrático em substituição às monarquias absolutistas existentes em sua época. Ele também dedicou seus esforços a compreender, deforma crítica, o próprio regime monárquico, estando conscientedos obstáculos aserem vencidos para que esta forma política fosse superada em direção a outras mais próximas de seus ideais, nas quais todos os cidadãos poderiam participar ativamente da administração do governo. Assim sendo, a discussão que será desenvolvida aqui tratará de alguns aspectos da reflexão de Rousseau sobre a monarquia, partindo de sua crítica ao regime até chegar a suas propostas concretas para possíveis reformas do mesmo.

Em seu texto político mais importante, o Contrato Social, de 1762, Rousseau não poderia deixar de tecer considerações sobre a monarquia em sua análise sobre os diferentes tipos de governo possíveis, e, mesmo quando ele parecia estar tratando do regime monárquico em geral, certamente era o Estado absolutista que, em última instância, tinha em mente, de modo que suas fortes acusações contra o poder real não se separam da crítica que ele dirige à civilização de sua época. Tal crítica baseava-se em princípios éticos, desafiando também a separação entre política e moral sobre a qual a monarquia absoluta se erigira, ${ }^{2}$ pois, como a metodologia de análise sintetizada por Rousseau no Emilio postula, "É preciso estudar a sociedade pelos homens, e os homens pela sociedade; quem quiser tratar separadamente a política e a moral nada entenderá de nenhuma das duas", 3

\footnotetext{
1 Mestre em História Social pelo Programa Associado de Pós-Graduação em História Uem/Uel. Autor de O Senhor das Letras: 0 Antigo Regime e a Modernidade na literatura voltaireana. Maringá: Eduem, 2000.

2 Kosel.ıeck, R. Crítica e crise: uma contribuição à patogênese do mundo burguês. Trad. Luciana V.-B. CasteloBranco. Rio de Janeiro: Eduerj/Contraponto, 1999.

3 Rousseau, J.-J. Emilio ou Da educação. Trad. Roberto Leal Ferreira. São Paulo: Martins Fontes, 1995. p. 309.
} 
Após definir o rei como um indivíduo que representa um ser coletivo, isto é, o conjunto do povo, e que detém em suas mãos o controle pessoal das leis e da máquina estatal, Rousseau afirma que é na monarquia que as ações do governante têm maior força, pois não são abaladas por movimentos conflitantes, visto que tudo se dirige para um mesmo objetivo. "Se não existe, porém, um Governo que possua mais vigor", escreve o filósofo, "não há absolutamente outro em que a vontade particular disponha de mais império e mais facilmente domine as outras; é verdade que tudo se movimenta para 0 mesmo fim, mas esse objetivo não é o da felicidade pública". ${ }^{4}$ Assim, ainda que o rei disponha dos meios mais poderosos para fazer cumprir suas determinações, estando acima dos partidos rivais, isto não resulta necessariamente em benefício do povo. Para Rousseau, os interesses do monarca se sobrepõem aos dos súditos que ele comanda, e a vontade do povo raramente coincide com os desejos pessoais do rei.

Rousseau não apenas enxergou na monarquia a existência de um descompasso entre os desejos do povo e do governante, mas denunciou neste último a ânsia de ampliar ao máximo o grau de seu poder. Os reis querem ser absolutos, diz o autor, e não medem esforços para atingir essa meta. Alguns aconselham os príncipes a conquistar o amor do povo. Porém, os monarcas sabem que esse é um poder precário e condicional, e buscam algo mais sólido em que se apoiar:

Os melhores reis querem ser maus, caso lhes agrade, sem deixar de ser os senhores. Será grato a um pregador político dizer-lhes que, sendo sua força a do povo, seu maior interesse estará em ser o povo florescente, numeroso, temível: eles sabem muito bem que isso não é verdade. 0 seu interesse pessoal estará principalmente em ser o povo fraco, miserável, e nunca possa oferecer-lhes resistência. Creio que, supondo-se os súditos sempre perfeitamente submissos, o interesse do príncipe seria então que o povo se tornasse potente a fim de que essa força, sendo a sua, o tornasse temível aos vizinhos, mas como tal interesse só é secundário e subordinado, e como as duas suposições se mostram incompatíveis, parece natural que os príncipes prefiram a máxima que lhes seja mais imediatamente útil. ${ }^{5}$

Na perspectiva rousseauniana, por conseguinte, a grandeza do rei é diretamente proporcional à fraqueza dos súditos. Não era também sem motivo, portanto, que os reis europeus, o da França inclusive, faziam tão pouco para suprimir, ou mesmo amenizar, as desigualdades que mantinham a maior parte de seus governados na pobreza, enquanto 0

\footnotetext{
4 Rousseau, J.-J. Do contrato social. In: Rousseau. São Paulo: Abril Cultural, 1973. (Os Pensadores). p. 94-95.
}

5 Id. Ib., p. 95. 
fausto da corte real permanecia intocado: afinal, um povo miserável é mais fácil de subjugar, e os reis preferiam sacrificar a prosperidade do reino por não desejarem obstáculos à sua autoridade dentro de seus próprios domínios.

0 regime monárquico, prossegue Rousseau em sua crítica, é mais conveniente aos grandes Estados, mas isto não significa queeles sejam fáceis de governarpor umúnico indivíduo. ${ }^{6}$ Nas grandes monarquias, "há uma grande distância entre o príncipe e o povo, efalta coesão ao Estado. Para constituí-la, necessitam-se, pois, ordens intermediárias; precisa-se dos príncipes, dos grandes, da nobreza para desempenhá-las" 7 Cria-se então uma estrutura administrativa que devese encarregar de levar a autoridade real a todos os súditos, eessa estruturaéresponsável pelo estabelecimento de novas desigualdades entre os membros da nação, na medida em que gera uma elite colocada acima do povo comum. Um problema fundamental na composição dessa elite, que Rousseau considera um defeito "essencial e inevitável" do governo monárquico, é que os homens que assumem os primeiros postos no Estado "não passam, comumente, de pequenos trapalhões, pequenos intrigantes, cujos pequenos talentos, que nas cortesfacilitam 0 acesso aos grandes postos, só servem para mostrar ao público, assim que ascendem, sua inépcia". Diferentemente das repúblicas, em que o mérito e a capacidade dos indivíduos conduzem-nos ao Estado graças ao voto do povo, na monarquia, levados às dignidades do governo por motivos alheios à sua competência, esses homens de "pequenas virtudes" são incapazes de aproveitar todos os recursos de que dispõem em benefício do bem público.

A competência do governante máximo também foi devidamente considerada por Rousseau, e de um ponto de vista educacional. 0 autor partia do pressuposto de que os príncipes, como quaisquer homens, precisavam receber uma formação adequadaà função que deveriam executar, a fim de que seus governos fossem pelo menos livres de alguns erros, já que vários outros seriam inevitáveis dada a própria essência do regime monárquico. Como se vê, o tema da educação assume novamente na obra do filósofo suíço um lugar fundamental. Assim como o texto do Emilio propõe uma pedagogia cujo objetivo é antes evitar o mal do que instigar o bem, o Contrato Social contém a afirmação de que os reis devem aprender a obedecer ao invés de serem educados para mandar:

Tudo concorre para privar de justiça e de razão um homem elevado à posição de comandar os demais. Diz-se que é muito trabalhoso ensinar aos jovens príncipes a arte de reinar; não parece trazer-lhes proveito tal educação. Seria melhor começar

6 Esse foi, aliás, um dos problemas de que Rousseau se ocupou em suas Considerações sobre o governo da Polônia (de 1771) ao fazer sua proposta de reforma para as estruturas políticas desse reino europeu.

7 Roussenu,J.-J. Do contrato social. p. 96.

$s$ Id. Ib., p. 96. 
por ensinar-lhes a arte de obedecer. Os maiores reis que a História celebra não foram educados para reinar; é uma ciência que nunca se possui menos do que depois de tê-la aprendido demais, e que melhor se adquire obedecendo do que comandando. ${ }^{9}$

Se Rousseau defendia que a criança tem de ser preservada da corrupção moral para que a voz da consciência - que nela existiria naturalmente ${ }^{10}$ - se fortaleça e possa ser sempre ouvida e respeitada na vida adulta, é necessário que os príncipes, em razão das responsabilidades inerentes à sua condição na comunidade política, sejam educados de tal forma que 0 aprendizado da obediência refreie neles, mais tarde, as tendências despóticas que o poder certamente lhes instigará, bem como lhes ensine a respeitar a autoridade das leis e os direitos dos súditos. Contudo, Rousseau sabia bem que dificilmente os príncipes recebiam tal tipo de educação, e manifestou todo o seu pessimismo quanto aos monarcas que sempre teriam sua formação moral prejudicada pelos ensinamentos nocivos adquiridos na juventude e pelos vícios da autoridade que estavam destinados a desempenhar. Assim, ele se pergunta: "se a educação real corrompe necessariamente aqueles que a recebem, que se deve esperar de um séquiito de homens educados para reinar? É, pois, querer iludir-se, confundir o Governo real com o de um bom rei. Para ver o que é esse Governo em si mesmo, impõe-se observá-lo quando os príncipes são tacanhos ou maus, pois chegarão assim ao trono ou o trono assim os tornará". "

A questão da escolha e dasucessão dos chefes supremoséum outro inconveniente que Rousseau encontrou na monarquia. Se o rei fosse determinado por eleições, sempre haveria a possibilidade de tumultos entre o fim de um governo e o princípio de outro, além da corrupção poder influir no resultado do processo eleitoral. Mas, se a coroa jáhavia se tornado hereditária, "mais se desejou o risco de aceitar como chefes crianças, monstros e imbecis, a ter de discutir sobre a escolha de bons reis". ${ }^{12}$ Comose vê, Rousseau estava bem longe de acreditar naidéia de que as famílias reais possuíam virtudes especiais para governar os povos, virtudes que seriam transmitidas pelos reis a seus descendentes pelo sangue sagrado que corria em suas veias. ${ }^{13}$ Certamente, a teoria do direito divino não pressupunha que o monarca deveria necessariamente

9 Id. Ib., p. 97.

10 "Existe, pois, no fundo das almas um princípio inato de justiça e de virtude a partir do qual, apesar de nossas próprias máximas, julgamos nossas ações e as de outrem como boas ou más, e é a esse princípio que dou o nome de consciência." Rousseau, J.-J. Emilio ou Da educação. Trad. Roberto Leal Ferreira. São Paulo: Martins Fontes, 1995. p. 390.

11 Roussead, J.-J. Do contrato social. p. 98.

12 Id. Ib., p. 97.

${ }^{13}$ Com isto, o filósofo contrapunha-se a uma certa imagem real que, nascida ainda na Idade Média e reforçada na Época Moderna, apresentava o monarca como um ser místico: "É a virtude do sangue que corre por suas veias 
ser um bom governante, mas, se os filhos dos reis podiam ser "monstros e imbecis" - e na história havia diversos exemplos -, como continuar sustentando a crença da sacralidade da descendência aristocrática, uma das pedras angulares da monarquia absolutista, ao invés de ver na hereditariedade da coroa a fonte de males e não de prosperidade?

Segundo Rousseau, antes dele existiram vários autores que pensaram a respeito de problemas como esse, refletindo sobre o fato de que nem sempre a realeza é um exemplo de virtude. Ora, escreve o filósofo,

Essas dificuldades não escaparam a nossos autores, mas eles em absoluto não se embaraçaram com elas. 0 remédio, dizem eles, é obedecer sem murmurar. Deus dá os maus reis em sua cólera e devemos suportá-los como castigos do céu. Sem dúvida, tal discurso é edificante, mas não sei se não conviria mais num púlpito do que num livro de política. Que dizer de um médico que promete milagres, mas cuja arte se limita a exortar seu doente à paciência? Sabemos muito bem que devemos agüentar um mau Governo quando o temos; a questão está em encontrar um bom. ${ }^{14}$

Essa alusão aos defensores da teoria do direito divino dos reis éfeita por Rousseau com um duplo intuito. Em primeiro lugar, ela objetiva refutar tal teoria, reclamando umadistinção entre os domínios da religião e da política: o discurso religioso que conclama a uma obediência devota aos reis, ainda quesejam tiranos, deveser relegado apenas ao espaço que lhe cabe, ou seja, às igrejas. Em segundo lugar, ela tem em mira indicar uma nova abordagem do problema político: não se trata mais de justificar aquilo que existe - os abusos do poder inclusive apelando para o sobrenatural, mas de enxergar a realidade com olhos críticos paraser capaz de propor a construção de algo novo e melhor.

Após essa incursão inicial pelo pensamento de Rousseau sobre a monarquia, cabe uma pergunta: o filósofo suíço não teria jamais escrito palavras favoráveis em relação a esse regime político? Ora, não obstante ter considerado a monarquia condenável por diversos motivos, Rousseau não pregava sua abolição imediata em todos os casos em prol da adoção da democracia participativa, como uma leitura restrita ao Contrato Social

que faz com que vivam seus súditos, que assegura aos seus a vitória nas guerras, os êxitos culturais". LoPEs, MARCos ANTôNIO. A imagem da realeza: simbolismo monárquico no Antigo Regime. São Paulo: Ática, 1994. p. 39. Visto que os reis franceses seriam herdeiros de uma antiga linhagem ungida por Deus, a continuidade de sua descendência era vista como fundamental para a existência do próprio reino. E tamanha era a crença no poder sagrado dos reis, que, como M. BL.ocH demonstrou, ainda na Idade Moderna, os monarcas da França e da Inglaterra realizavam rituais supostamente capazes de curar doenças de forma milagrosa. BLoCH, MARc. Os reis taumaturgos: o caráter sobrenatural do poder régio, França e Inglaterra. Trad. Júlia Mainardi. São Paulo: Companhia das Letras, 1993.

${ }^{14}$ Id. Ib., p. 98. 
poderia sugerir. Há obras do autor em que, de fato, a monarquia aparece de uma forma bem menos negativa, ainda que não isenta de problemas. Tal é o caso do texto literário intitulado A Rainha Fantasiosa. Neste conto de fadas, Rousseau relatou alguns acontecimentos dignos de nota ocorridos nos domínios de um certo rei Fênix. Segundo Jalamir, o narrador da estória, Fênix era um monarca que amava seu povo e que,

consequientemente, era adorado por ele. Ele havia empregado todos os seus esforços para encontrar ministros igualmente bem intencionados, mas, tendo reconhecido enfim a loucura de uma tal busca, ocupou-se da tarefa de fazer totalmente sozinho todas as coisas que podia subtrair à atividade nociva deles. Como estava corajosamente obstinado no bizarro projeto de tornar seus súditos felizes, ele agia de acordo, e uma conduta tão singular fazia-o passar por um ridículo inesquecível entre os grandes. 0 povo $o$ bendizia, mas na corte ele passava por louco. ${ }^{15}$

No reino imaginário do conto, existia um governante que estava unido ao povo por fortes laços afetivos, uma vez que seu objetivo maior era a bem-aventurança dos súditos. Se Rousseau afirmou alhures que a distância entre o príncipe e o povo prejudicava a coesão do Estado e exigia a criação de ordens intermediárias entre eles, no reinado de Fênix isso não era um problema, pois o rei assumira sozinho o trabalho que deveria caber aos ministros e fora bem sucedido em tal empreitada.

Entretanto, Fênix era um indivíduo extraordinário, e temia que toda a sua obra se perdesse ao fim de seu reinado. Ele precisava garantir que seu herdeiro e sucessor prosseguisse na mesma direção, mas sua esposa, a rainha Fantasiosa, cujo caráter era bem descrito por seu nome, preferia que os filhos gêmeos recém-nascidos fossem educados para os prazeres fúteis da corte e não para a missão de governar. Afada Discreta, amiga dos governantes, prometeu dar às duas crianças, num passe de mágica, o caráter que os pais desejassem e, enquanto a rainha quis que uma das crianças fosse bela e dotada de boas maneiras - ainda que estúpida,- 0 rei pediu que a sensatez fosse a característica principal da outra. Ora, a leitura dessa parte do conto mostra que Rousseau também se preocupou em apontar quais deveriam ser as virtudes mais aconselháveis aos reis. Talvez não caiba a essa obra do filósofo suíço a classificação de "espelho dos príncipes", ${ }^{16}$ mas se pode inferir de sua análise um certo ideal de conduta indicado aos monarcas. Neste sentido,

${ }_{15}$ Rousseau, J.-J. La reine fantasque. Disponível em: <http://un2sg4.unige.ch/ athena/rousseau/jir_fant.rtf> Acesso em: 05 ago. 2001.

${ }^{16} 0$ espelho dos príncipes (miroir des princes) constituía um antigo gênero literário cujo objetivo era definir as virtudes mais adequadas aos monarcas. Ver: LOPES, MARCos ANTÔNIO. Voltaire político: espelhos para príncipes de um novo tempo. São Paulo: Editora Unesp, 2004. 
Rousseau manifesta uma opinião contrária à de Maquiavel a respeito da importância da prudência na ação do governante. 0 escritor italiano acreditava que a conjugação da virtù pessoal com as benesses da fortuna era o fator determinante do sucesso de um príncipe, de modo que a prudência, uma virtude cristã, teria uma posição pouco relevante nesse caso. Rousseau, por outro lado, pinta um retrato da monarquia em que a prudência do governante, ou sua falta, desempenha um papel decisivo na preservação do reino e na felicidade do povo. Ao comparar as qualidades e os defeitos que os gêmeos do conto deveriam desenvolver no futuro, de acordo com os desejos de seus pais, o sábio druidainterlocutor de Jalamir - prevê os problemas que o conflito entre a imprudência de um e a sensatez da outra trariam ao país:

Teu príncipe Capricho fará virar a cabeça de todo o mundo e será muito bom imitador de sua mãe para não ser seu tormento. Ele perturbará o reino querendo reformá-lo. Para tornar seus súditos felizes, ele os deixará em desespero, tomando seus próprios erros pelos dos outros, e injusto por ter sido imprudente, o pesar por suas faltas o fará cometê-las de novo. Como a sabedoria não o conduzirá jamais, o bem que ele quiser fazer aumentará o mal que ele terá feito. Em uma palavra, ainda que no fundo ele seja bom, sensível e generoso, suas próprias virtudes o levarão ao erro e apenas seu aturdimento, unido a seu poder, o fará mais odiado do que o teria feito uma maldade bem pensada. De outro lado, tua princesa Razão, nova heroína do país das fadas, tornar-se-á um prodígio de sabedoria e de prudência, e sem ter adoradores se fará a tal ponto amar pelo povo que cada um fará votos de ser governado por ela. Sua boa conduta vantajosa a todo o mundo e a ela mesma não causará problemas a não ser a seu irmão, cujos vícios opor-se-ão sem cessar às virtudes dela, e a quem a prevenção pública dará todos os defeitos que ela não terá, mesmo quando ele próprio não os tiver. ${ }^{17}$

Acreditando que o príncipe teria recebido da fada um caráter igual ao da rainha, o rei já se lamentava pelo futuro de seu povo. Afalta das qualidades necessárias a um bom monarca faria malograr todas as medidas tomadas pelo sucessor de Fênix, mesmo as mais bem-intencionadas dentre elas. Aos súditos caberia apenas se resignar com a situação e aceitar as ordens de seu governante legítimo, pois as leis da sucessão ao trono deveriam ser respeitadas, ainda que às custas da felicidade do reino. Como Rousseau havia observado no Contrato Social, sempre há aqueles que defendem incondicionalmente o sagrado direito dos monarcas de agir como bem lhes apetecer. De acordo com o druida, não

${ }_{17}$ Rousseau, J.-J. La reine fantasque. Disponível em: <http://un2sg4.unige.ch/ athena/rousseau/jir_fant.rtf> Acesso em: 05 ago. 2001. 
faltariam doutores para expor as consequências nefastas do não cumprimento da tradição e para defender a idéia de que

vale mais que 0 povo obedeça cegamente aos fanáticos que 0 azar pode lhes dar por mestres do que escolher ele mesmo chefes sensatos; que ainda que se interditasse a um louco o governo de seus próprios bens, é bom deixar-lhe a suprema disposição de nossos bens e vidas; que o mais insensato dos homens é ainda preferível à mais sábia das mulheres; e que se o macho ou o primogênito fosse um macaco ou um lobo, seria necessário, em boa política, que uma heroína ou um anjo que nasceu depois obedecesse às vontades dele. ${ }^{18}$

Recorrendo à ironia de um modo que lembra muito a acidez do estilo voltairiano, Rousseau expõe assim a irracionalidade presente em uma importante questão política. Ao invés de criar uma forma de governo que sirva em primeiro lugar ao bem público e na qual os interesses particulares curvem-se diante das necessidades coletivas, os homens preferem muitas vezes submeter-se ao arbítrio de um insano coroado pela forçados costumes.

Contudo, aquilo que parecia uma desgraça mostrou ser apenas um equívoco, pois a fada na verdade havia concedido ao menino uma personalidade semelhante à de seu pai. Dessa forma, o príncipe Razão transformou-se, desde a infância, num modelo de governante na perspectiva rousseauniana. Descrevendo a boa conduta do jovem ao assumir o Estado no lugar de seu pai, o filósofo sintetizou as virtudes que caracterizaram seu governo, ou seja, a prudência, a busca da paze a eficiência administrativa:

Alçado ao trono após a morte do rei, Razão fez muito de bem e pouco barulho. Procurando antes cumprir seus deveres que adquirir reputação, ele não fez guerra aos estrangeiros nem violência a seus súditos, e recebeu mais bendizeres do que elogios. Todos os projetos feitos no reinado precedente foram executados no dele, e ao passar da dominação do pai para a do filho, o povo foi duas vezes feliz crendo não ter mudado de senhor. ${ }^{19}$

0 reinado de Razão teria sido tão excelente quanto o de seu pai, e tão concorde com o dele, que se constituiu numa notável exceção em se tratando de um regime monárquico. Rousseau escreveu no Contrato social que a passagem do governo de um

\footnotetext{
${ }^{18}$ RousseAu,J.-J.LLa reine fantasque. Disponível em: <http://un2sg4.unige.ch/athena/rousseau/jir_fant.rtf $>$ Acesso em: 05 ago. 2001.

${ }^{19}$ Rousseau,J.J. La reine fantasque. Disponível em: <http://un2sg4.unige.ch/ athena/rousseau/jir_fant.rtf $>$ Acesso em: 05 ago. 2001.
} 
rei para o de outro sempre trazia sérios problemas de continuidade, pois o Estado monárquico, "segundo o caráter do príncipe que reina ou das pessoas que reinam por ele, não pode manter muito tempo um objetivo fixo nem uma conduta conseqüente", já que "a máxima comum a todos os ministros e a quase todos os reis é a de tomar em todos os assuntos posição contrária à de seu predecessor". ${ }^{20}$ Fênix e Razão não apenas representariam, enfim, a realeza ideal, como também a negação dos casos concretos a partir dos quais Rousseau construiu sua teoria.

Poder-se-ia, com bons argumentos, objetar dizendo que, por se tratar de um conto de fadas, a estória desses dois monarcas exemplares não serviria para expor as verdadeiras idéias de Rousseau sobre a realeza. Contudo, as coisas não são assim tão simples. A imagem da realeza apresentada em $A$ Rainba Fantasiosa é, certamente, a descrição de uma monarquia ideal, mas o Estado democrático proposto no Contrato Social também não é a descrição de uma república ideal? Sabe-se muito bem que a monarquia era o regime político predominante na Europa setecentista, e a preocupação do filósofo suíço em mostrar, por diversos meios, como ela poderia ser aperfeiçoada não é uma vertente secundária - ou utópica - de seu pensamento. A despeito de sua apaixonada defesa da democracia, Rousseau era capaz de demonstrar um considerável realismo político, e conhecia os limites e os perigos das propostas revolucionárias. Em suas Considerações sobre o governo da Polônia, por exemplo, o autor reconhece que era impossível a um Estado grande como a Polônia dispensar um chefe supremo vitalício. 0 que os poloneses deveriam fazer seria reformar a monarquia de modo que o rei deixasse de ser 0 inimigo nato da nação, pois esse mal, escreve-lhes Rousseau, "não éde tal maneira inerente a esse posto a ponto de não podermos dele isolá-lo ou, ao menos, diminuí-lo consideravelmente. Não há tentação sem esperança. Tornai a usurpação impossível a vossos reis e eliminarlhes-eis a fantasia; e eles colocarão, em bem vos governar e vos defender, todos os esforços que fazem atualmente para sujeitar-nos". ${ }^{21} 0$ primeiro passo rumo a tal objetivo tinha de ser a limitação das atribuições do monarca - ele não poderia nomear, a seu bel prazer, todos os membros do governo - e de seus recursos financeiros ${ }^{22}$ - o Estado pagaria suas despesas. Além disso, a coroa, que na Polônia ainda era eletiva, jamais poderia ser transmitida de pai para filho; caso contrário, a liberdade desejada pelos súditos seria

\footnotetext{
${ }^{20}$ Rousseau, J.-J. Do contrato social. pp. 97-8.

${ }^{21}$ Rousseau,J.-J. Considerações sobre o governo da Polônia e sua reforma projetada. Trad. Luiz Roberto Salinas Fortes. São Paulo: Brasiliense: 1982. p. 59.

${ }^{22} \mathrm{Na}$ monarquia francesa, assim como em outros reinos europeus, não havia uma separação clara entre o erário público e os bens da familia real. A esse respeito ver EluAs, NoRBERT. A sociedade de corte. Trad. Ana Maria Alves. 2. ed. Lisboa: Estampa, 1995.
} 
banida para sempre.

Para Rousseau, a autoridade absoluta dos reis tinha de ser combatida, ou então a liberdade dos povos jamais seria garantida. Ele colocava o primado da lei acima da autoridade real, exigindo aquilo que mais tarde Weber chamou de dominação legal. ${ }^{23} \mathrm{~A}$ modernização da realeza passava, então, pela reformulação das bases e do alcance de seu poder, condição essencial para que os reis fossem mais eficazes na condução do Estado, 0 que exigia que a estrutura administrativa como um todo passasse por reformas que tornariam seu funcionamento mais racional.

Ora, em sua crítica ao regime monárquico, Rousseau falou dos "pequenos trapalhões" e dos "pequenos intrigantes" que usavam seus "pequenos talentos" como cortesãos para alcançar grandes postos no governo, apesar de sua inépcia pessoal. Esses comentários remetem à dinâmica da sociedade de corte no interior do Antigo Regime. Nela, as cerimônias da etiqueta, por mais opressivas que pudessem ser para seus executores, eram continuamente reiteradas porque estavam no cerne da ordenação social: como cada um executava uma determinada ação em decorrência de seu status, qualquer modificação nos papéis significava possivelmente o fim de um privilégio e, com isto, a diminuição do prestígio de um nobre frente aos demais. Norbert Elias nos diz que "a verdadeira posição de um indivíduo na trama da sociedade de corte era sempre determinada por estes dois fatores em simultâneo: a posição oficial e a posição de poder efetivo. 0 segundo fator era, em última análise, o mais importante". ${ }^{4}$ Sujeitos ao poder da opinião de seus pares, os nobres tinham de agir com desenvoltura na corte para serem reconhecidos como realmente dignos de seu título, representando com maestria os papéis referentes às suas posições; caso contrário seriam superados na competição pelo prestígio próprio de sua configuração social. Considerando o poder do rei para nomear, de acordo com sua própria vontade, as pessoas que ocupavam os cargos no Estado, em funções como os ministérios, os governos provinciais e as intendências, os cortesãos utilizavam seu prestígio junto a ele para obter tais posições privilegiadas, as quais traziam grandes possibilidades de enriquecimento. 0 que Rousseau assinalou com veemência foi o fato das escolhas do monarca nem sempre se basearem nas capacidades dos indivíduos para desempenhar as atividades necessárias a seu cargo, mas sim justamente nas intrincadas relações de poder que se davam na corte.

Não bastasse esse problema, o filósofo também via na venalidade dos cargos

${ }^{23}$ Segundo MAx WEBER, na dominação legal, "obedece-se não à pessoa em virtude de seu direito próprio, mas à regra estatuída, que estabelece ao mesmo tempo a quem e em que medida se deve obedecer. Também quem ordena obedece, ao emitir uma ordem, a uma regra: à 'lei' ou 'regulamento' de uma norma formalmente abstrata". Weber, MAx. Os três tipos puros de dominação legítima. In: ——. Sociologia. 6. ed. Trad. Amélia Cohn e Gabriel Cohn. São Paulo: Ática, 1997. pp. 128-141. (Grandes Cientistas Sociais). p. 129.

${ }^{24}$ EliAs, NoRBERT. A sociedade de corte. p. 65. 
públicos um outro mal a ser extirpado. Para aumentar sua receita, a monarquia francesa criara a chamada noblesse de robe, uma aristocracia cuja posição advinha de ter comprado o direito de exercer uma determinada função na burocracia estatal que trazia consigo um título de nobreza. Segundo Perry Anderson, "O sistema nasceu no século XVI e tornou-se um esteio financeiro fundamental dos Estados absolutistas durante o século XVII. O seu caráter flagrantemente parasitário é evidente: em situações extremas (a França durante a década de 1630, por exemplo), poderia custar ao orçamento real em desembolsos (via o arrendamento da coleta ou as isenções) o mesmo que fornecia em remunerações". ${ }^{25}$ Nem todos os cargos comprados levavam ao enobrecimento, mas as vantagens que seu exercício propiciava geralmente valiam o investimento. Tocqueville diz que "os burgueses procuravam essas funções com um ardor sem par. Logo que um deles tinha um pequeno capital, em vez de empregá-lo num negócio, utilizava-o imediatamente para comprar um emprego público" ${ }^{26}$ Além de influir negativamente na economia do país desestimulando as aplicações financeiras em atividades produtivas - algo apontado por Tocqueville -, tal costume levava também a outra dificuldade: ele impedia que muitas pessoas capazes desempenhassem serviços úteis ao governo, ao mesmo tempo em que abria as portas do mesmo à incompetência e à corrupção.

No pensamento de Rousseau, a condenação à venalidade dos cargos era uma decorrência lógica de sua teoria política. No Discurso sobre a origem e os fundamentos da desigualdade entre os homens, de 1754, o autor traçou as origens prováveis do Estado apresentando-as como uma conseqüência do surgimento da desigualdade econômica entre os homens. A submissão dos pobres aos ricos constituía a essência de um contrato social perverso cujos termos era preciso reverter para tornar possível a liberdade. Assim, escreve Rousseau no Discurso sobre a economia política, de 1755, uma das tarefas primordiais do governo deveria residir no abrandamento da desigualdade das riquezas, não apenas evitando que as fortunas pudessem ser aumentadas, como também impedindo 0 alastramento da pobreza entre os cidadãos. Isto porque a riqueza de poucos e a pobreza de muitos são, nas palavras do filósofo, "as causas principais da opulência e da miséria, da substituição do interesse público pelo particular, da raiva mútua dos cidadãos, de sua indiferença pela causa comum, da corrupção do povo e do enfraquecimento de todos os esforços do governo" ${ }^{27}$ Como a desigualdade econômica foi

\footnotetext{
${ }^{25}$ Anderson, Perry. Linhagens do Estado absolutista. Trad. João R. M. Filho. São Paulo: Brasiliense, 1985. p. 33.

${ }^{26}$ TocQueviluE, Alexis DE. O Antigo Regime e a Revolução. 2. ed. Trad. Yvonne Jean. Brasília: Editora UnB, 1982. p. 114.
} 
a causa principal do nascimento do Estado, somente esta instituição teria os meios para combater os males que sua existência perpetuou na sociedade. Tendo em mente a época em que vivia e o desenvolvimento que nela alcançaram as artes e os ofícios, bem como a relação entre tais atividades e o papel desempenhado pelo governo, Rousseau pintou um quadro dos problemas que os governantes precisavam visualizar com clareza a fim de solucioná-los:

os homens desigualmente distribuídos pelo território e amontoados num lugar enquanto os outros ficam despovoados; as artes da diversão e de pouca habilidade são mantidas às expensas dos trabalhos úteis e penosos; a agricultura sacrificada pelo comércio; o publicano tornando-se necessário pela má administração das finanças do Estado; enfim, a venalidade levada a tal excesso que a consideração se mantém pelas armas e as próprias virtudes são vendidas por dinheiro. Conseqüentemente, esses são males que, quando são percebidos, dificilmente são sanados, mas que uma administração sábia deve prevenir para manter, junto com os bons costumes, 0 respeito pelas leis, 0 amor à pátria e 0 vigor da vontade geral. ${ }^{28}$

Para Rousseau, servir ao Estado devia ser o mesmo que realizar uma tarefa cívica motivada pelo patriotismo, e a venalidade dos cargos era um grave sintoma de degeneração política. Desse modo, sendo o serviço público ao mesmo tempo um dever patriótico e um direito cívico, Rousseau acreditava que, para o bem da nação, este jamais poderia ser um privilégio restrito a poucos. "Então", escreveu ofilósofo, "que a pátria se mostre a mãe comum de todos os cidadãos, que as vantagens que usufruem em seu país a tornem amada, que o governo os deixe participar da administração pública para perceberem que estão em casae que as leis sejam a seus olhos garantias de sua liberdade" . ${ }^{29}$ Em uma democracia, o desejo do autor seria fácil de realizar. Entretanto, como a participação mais ampla do povo no governo seria possível numa época em que o regime monárquico predominava? Confrontado com essa questão prática no tocante à Polônia, Rousseau teve de lidar com uma situação concreta de reforma administrativa, e o resultado de suas reflexões foi um "projeto para submeter a uma marchagradual todos os membros do governo".

De acordo com tal projeto, os membros ativos da República - leia-se o Estado polonês - seriam divididos em três classes devidamente identificadas por distintivos especiais. Para entrar na primeira delas, os jovens passariam por um período de experiência

${ }^{27}$ Rousseau, J.-J. Discurso sobre a economia politica e Do contrato social. Trad. Maria Constança P. Pissara. Petrópolis: Vozes, 1995. p. 38-39.

${ }^{28}$ Id. ib., p. 39.

${ }^{29}$ Id. Ib., p. 38. 
de três anos em funções como a de advogado, assessor, juiz e administrador. Após esse período, um exame severo da conduta desses funcionários por parte da dietina $a^{30}$ provincial decidiria pela continuidade de suas carreiras no governo. Os bem-sucedidos, que receberiam o título de Servidores do Estado, poderiam então aspirar à segunda classe, a qual somente admitiria os indivíduos que houvessem sido eleitos núncios na dieta por três vezes e recebido a aprovação de seus constituintes. Os membros do segundo nível seriam chamados de Cidadãos de escolha, e todos os componentes do senado precisariam passar por ele. A terceira e mais elevada das classes, enfim, abrangeria os que tivessem recebido o cargo de senador-deputado por três vezes, sendo avaliado com méritos por seus pares. Caberia a esses distintos cidadãos os títulos de grande castelão e palatino, este último destinado aos que ocupariam, em caráter vitalício, os postos mais eminentes da República, podendo inclusive chegar ao trono. Em todos os níveis, como se pode ver, Rousseau defende a necessidade da aprovação da "voz pública", o que exigiria a transparência dos atos dos funcionários no exercício de suas funções. Somente a competência e a virtude tinham de ser levadas em conta na elevação de um indivíduo dentro da hierarquia estatal.

Mas, e quanto ao restante da população? Como incluí-lo na "marcha" junto com os nobres e os magistrados? Rousseau propõe que essa mudança seja feita gradualmente, sem uma revolução sensível, de forma que

a parte mais numerosa da nação se ligue de afeição à pátria e mesmo ao governo. Isso seria obtido por dois meios: o primeiro, uma exata observação da justiça, de sorte que 0 servo e o plebeu, não tendo nunca que temer virem a ser injustamente humilhados pelo nobre, curem-se da aversão que devem ter naturalmente por ele. Isto pede uma grande reforma nos tribunais e um cuidado particular na formação do corpo dos advogados. 0 segundo meio, sem o qual o primeiro não é nada, é abrir uma porta aos servos para adquirir a liberdade e aos burgueses para adquirir a nobreza. ${ }^{31}$

Aexecução do segundo meio seriauma atribuição de assembléias especialmente reunidas para avaliar a conduta de servos e burgueses a fim de decidir sobre o mérito de sua elevação de status. Assim como os funcionários, o povo comum também teria de se submeter à aprovação da "voz pública". Rousseau chega a prever um futuro distante em que a consecução de seu

\footnotetext{
${ }^{30}$ Os nobres poloneses reuniam-se periodicamente nas chamadas dietinas, ou dietas de palatinado, para nelas eleger os núncios encarregados de representá-los na dieta geral. Esta se reunia a cada dois anos e era composta do senado e dos representantes da nobreza; ela partilhava com o rei o poder legislativo.

${ }^{31}$ Rousseau, J.-J. Considerações sobre o governo da Polônia e sua reforma projetada. Trad. Luiz Roberto Salinas Fortes. São Paulo: Brasiliense: 1982. p. 94.
} 
projeto daria origem a comunas livres na Polônia, franqueando aos plebeus o direito de enviar deputados às dietinas e de participar do exército para defender o Estado. Os burgueses, por sua vez, concorreriam cada vez mais para a prosperidade da nação, pois seus esforços poderiam ser recompensados com diversas honrarias e distinções. Se suas sugestões fossem colocadas em prática com cautela eseguindo as lições da experiência, conclui o filósofo, "chegar-se-ia enfim a vivificar todas as partes da Polônia e a ligá-las de maneira a não fazer mais do que um mesmo corpo, cujo vigor e as forças seriam ao menos duplicadas com relação àquilo que podem ser hoje: e isto com a inestimável vantagem de ter evitado toda mudança viva e brusca e o perigo das revoluções" 32

0 plano traçado por Rousseau certamente obedecia a especificidades próprias da realidade polonesa, mas demonstra que o filósofo pensou seriamente em como tornar as monarquias em geral mais próximas de seu ideal de Estado. Para tanto, a coesão nacional precisava ser estabelecida no sentido de unir os grupos diversos que compunham os povos dos Antigos Regimes - nobres, burgueses e camponeses - no objetivo comum de servir à pátria. Com o passar do tempo, as desigualdades que os opunham acabariam sendo, se não abolidas, a menos minimizadas, e a vontade geral estaria cada vez mais próxima de ser o fundamento do corpo político. Naquela "voz pública" que tinha por meta avaliar as condutas de todos os membros do Estado pode-se ver o germe da vontade geral, e também uma extensão do desejo rousseauniano de transparência na política, de impedir que as ações individuais pudessem passar despercebidas aos olhos da comunidade civil, um anseio cuja relevância justifica-se pelo papel pessoal desempenhado na história por aqueles indivíduos especiais chamados monarcas. Afinal de contas, em uma época na qual os reis usufruíam um poder crucial sobre o destino das nações, era preciso encontrar os meios de impedir que os caprichos e as extravagâncias de um governante fantasioso perturbassem a vida dos súditos, bem como de garantir que a razão jamais estivesse distante dos tronos do mundo.

Recebido em outubro de 2004.

32 Id. Ib., pp. 97-8. A advertência de Rousseau contra o perigo das revoluções vai de encontro às interpretações de seu pensamento político que o consideram um precursor do movimento revolucionário que abalou a França no final do século XVIII. Bento Prado Jr. adverte os analistas da obra rousseauniana a respeito das leituras que, a posteriori, procuram encontrar nela um conteúdo revolucionário que o próprio filósofo suíço não teria percebido. Mencionando os usos feitos por Rousseau da palavra revolução em seus escritos, Prado Jr. afirma que, em se tratando de política, ela vem sempre carregada negativamente. PRADOJR, Bento. Prefácio. In: RousseAu,J.J. Discurso sobre a economia política e Do contrato social. Trad. Maria Constança P. Pissara. Petrópolis: Vozes, 1995. p. 7-18. 